\title{
Effect of a novel proteoglycan PTP1B inhibitor from Ganoderma lucidum on the amelioration of hyperglycaemia and dyslipidaemia in $d b / d b$ mice
}

\author{
Chen-Dong Wang ${ }^{1} \dagger$, Bao-Song Teng ${ }^{1} \dagger$, Yan-Ming $\mathrm{He}^{2} \dagger$, Jia-Sheng Wu ${ }^{3} \dagger$, Deng Pan ${ }^{1}$, Luan-Feng Pan ${ }^{4}$, \\ Dan Zhang ${ }^{2}$, Zhao-Hua Fan ${ }^{2}$, Hong-Jie Yang ${ }^{2 *}$ and Ping Zhou ${ }^{1 *}$ \\ ${ }^{1}$ Department of Macromolecular Science, Key Laboratory of Molecular Engineering of Polymers, Fudan University, Shanghai \\ 200433, People's Republic of China \\ ${ }^{2}$ Yueyang Hospital of Integrated Traditional Chinese and Western Medicine, Shanghai University of Traditional Chinese \\ Medicine, Shanghai 200437, People's Republic of China \\ ${ }^{3}$ Pharmacy College, Shanghai University of Traditional Chinese Medicine, Shanghai 201203, People's Republic of China \\ ${ }^{4}$ Laboratory of Molecular Biology, Shanghai Medical College, Fudan University, Shanghai 200032, People's Republic of \\ China
}

(Submitted 23 August 2011 - Final revision received 3 January 2012 - Accepted 9 January 2012 - First published online 27 March 2012)

\begin{abstract}
Protein tyrosine phosphatase 1B (PTP1B) is implicated in the negative regulation of the insulin signalling pathway by dephosphorylating the insulin receptor (IR) and IR substrates. Ganoderma lucidum has traditionally been used for the treatment of diabetes in Chinese medicine; however, its anti-diabetic potency and mechanism in vivo is still unclear. Our previously published study reported a novel proteoglycan PTP1B inhibitor, named Fudan-Yueyang-Ganoderma lucidum (FYGL) from G. lucidum, with a half-maximal inhibitory concentration $\left(\mathrm{IC}_{50}\right)$ value of $5.12(\operatorname{SEM} 0.05) \mu \mathrm{g} / \mathrm{ml}$, a protein:polyglycan ratio of $17: 77$ and $78 \%$ glucose in polysaccharide, and dominant amino acid residues of aspartic acid, glycine, glutamic acid, alanine, serine and threonine in protein. $F Y G L$ is capable of decreasing plasma glucose in streptozotocin-induced diabetic mice with a high safety of median lethal dose $\left(\mathrm{LD}_{50}\right)$ of $6 \mathrm{~g} / \mathrm{kg}$. In the present study, $\mathrm{C} 57 \mathrm{BL} / 6 \mathrm{db} / \mathrm{db}$ diabetic mice were trialed further using $F Y G L$ as well as metformin for comparison. Oral treatment with $F Y G L$ in $d b / d b$ diabetic mice for 4 weeks significantly $(P<0.01$ or 0.05$)$ decreased the fasting plasma glucose level, serum insulin concentration and the homeostasis model assessment of insulin resistance. FYGL also controlled the biochemistry indices relative to type 2 diabetes-accompanied lipidaemic disorders. Pharmacology research suggests that FYGL decreases the plasma glucose level by the mechanism of inhibiting PTP1B expression and activity, consequently, regulating the tyrosine phosphorylation level of the IR $\beta$-subunit and the level of hepatic glycogen, thus resulting in the improvement of insulin sensitivity. Therefore, FYGL is promising as an insulin sensitiser for the therapy of type 2 diabetes and accompanied dyslipidaemia.
\end{abstract}

Key words: Ganoderma lucidum: Protein tyrosine phosphatase 1B: Diabetes: $d b / d b$ Mice

Diabetes is recognised as a group of metabolic disorders with the common elements of hyperglycaemia and glucose intolerance, due to insulin deficiency or impaired insulin action ${ }^{(1)}$. As such, enhancing insulin sensitivity is a primary strategy to improve metabolic control in subjects with type 2 diabetes. Insulin acts as a ligand that binds to insulin receptors (IR) of insulin-sensitive tissues such as liver, skeletal muscle and adipose tissue. The coordinated tyrosine phosphorylation of receptors is essential for signalling pathways regulated by insulin and leptin. Protein tyrosine phosphatases (PTP) are the regulators of tyrosine phosphorylation-dependent cellular events that govern numerous critical physiological processes ${ }^{(2,3)}$. Among the PTP family members, PTP1B first purified from the PTP family in the human placenta ${ }^{(4)}$ is known to be a key negative regulator of the IR signal transduction pathway ${ }^{(5)}$. Vast amounts of studies on chemical, biochemical, cellular, animal

Abbreviations: BzN-EJJ-amide, $N$-benzoyl-L-glutamyl-(4-phosphono-(difluoromethyl))-L-phenylalanine-(4-phosphono-(difluoro-methyl))-L-phenylalanineamide; FYGL, Fudan-Yueyang-Ganoderma lucidum; JTT-551, monosodium (1[5-(1,1-dimethylethyl)thiazol-2-yl]methyl\}[(4-\{4-[4-(1-propylbutyl)phenoxy] methyllphenl)thiazol-2-yl]methyllamino)acetate; HDL-C, HDL-cholesterol; HOMA- $\beta$, homeostasis model assessment of $\beta$-cell function; HOMA-IR, homeostasis model assessment of insulin resistance; IR, insulin receptor; IRK, insulin receptor kinase; IRS, insulin receptor substrate; LDL-C, LDL-cholesterol; NC, nitrocellulose; PI3K, phosphatidylinositol 3-kinase; PKB, protein kinase B; PTP, protein tyrosine phosphatase; TC, total cholesterol.

*Corresponding authors: P. Zhou, fax +86 21 55664038, email pingzhou@fudan.edu.cn and H.-J. Yang, email yanghongjie1964@yahoo.com.cn

† These authors contributed equally to this work. 
and human genetic levels have identified the importance of PTP1B for both insulin and leptin signalling ${ }^{(5-12)}$. As an enzyme dephosphorylating the IR in the liver and skeletal muscle, PTP1B acts as an important mediator for the control of blood glucose levels and body weight through regulating IR and leptin signalling ${ }^{(6-8)}$. PTP1B interacts with and dephosphorylates the IR as well as the IR substrate (IRS). If PTP1B did not dephosphorylate the IRS, the phosphorylated IRS would serve as an adaptor protein and recruit phosphatidylinositol 3-kinase (PI3K) via the regulatory subunit; PI3K would then catalyse the conversion of phosphatidylinositol to 3,4-bis- and 3,4,5-trisphosphate that would stimulate the activity of phosphoinositide-dependent kinase-1. Together with phosphoinositide-dependent kinase-2, phosphoinositide-dependent kinases activate serine/threonine protein kinase (Akt or protein kinase $\mathrm{B}$ (PKB)), via the phosphorylation of a critical serine and threonine residue ${ }^{(9)}$. If PTP1B were overexpressed, then most of the IRS would be dephosphorylated and a series of enzymes such as PI3K and PKB participating in the process of glucose uptake would be inactivated since the insulin transduction pathway is blocked ${ }^{(10)}$. Insulin-resistant states show the increase in PTP1B activity ${ }^{(11)}$. Mice that lack PTP1B display an enhanced sensitivity to insulin, with increased or prolonged tyrosine phosphorylation of the IR in the liver and muscle ${ }^{(12)}$. In addition, PTP1B deficiency for PTP1B knockout suckling mice increases the content of glycogen and serum TAG in the liver, compared with that for wild-type controls ${ }^{(13)}$. On the basis of these findings, the inhibition of PTP1B has emerged as an attractive therapeutic strategy to treat type 2 diabetes and obesity. The dependence of diabetes and obesity on PTP1B has increased research interest for searching more efficient PTP1B inhibitors during the last decade ${ }^{(14-16)}$. Unfortunately, most of the small-molecule inhibitors of PTP1B have been proven difficult to be developed into effective drugs due to their low cell permeability and bioavailability ${ }^{(15,16)}$; efforts on finding more efficient PTP1B inhibitors are still undergoing.

Ganoderma lucidum is one of the oldest mushrooms used to treat many ailments including endocrine-related diseases in traditional Chinese medicine. Scientific investigations have confirmed the beneficial effects of bioactive components isolated from G. lucidum on the prevention and treatment of human diseases $^{(17-22)}$. Antihyperglycaemic effects of the active extracts from $G$. lucidum in vivo have already been reported ${ }^{(19-22)}$. As an important biologically active component in G. lucidum, polysaccharide is now arousing a great interest for its essential role in metabolism ${ }^{(20,22,23)}$. It is reported that the polysaccharide of $G$. lucidum exerts its antihyperglycaemic function by influencing the metabolic pathway of hepatic glycogen ${ }^{(21)}$. Studies ${ }^{(20,22)}$ have indicated that the polysaccharide of G. luci$d u m$ can promote the release of serum insulin by mediating the activity of various enzymes participating in glucose metabolism, and then decrease plasma glucose in vivo. In our previously published study ${ }^{(24)}$, a novel proteoglycan, named Fudan-Yueyang-G. lucidum (FYGL), from the fruiting bodies of $G$. lucidum was also reported to be capable of decreasing plasma glucose in streptozotocin-induced mice with a high safety of median lethal dose $\left(\mathrm{LD}_{50}\right)$ of $6 \mathrm{~g} / \mathrm{kg}$. FYGL shows an efficient PTP1B inhibitory potency with a half-maximal inhibitory concentration $\left(\mathrm{IC}_{50}\right)$ value of $5 \cdot 12(\mathrm{SEM} 0.05) \mu \mathrm{g} / \mathrm{ml}$ and competitive inhibition kinetics with the substrate of PTP1B in vitro. FYGL is a water-soluble proteoglycan covalently bonded with protein and polyglycan in a ratio of 17:77. Among six monosaccharides (glucose, arabinose, xylose, rhamnose, galactose and fructose) involved in $F Y G L$, the major monosaccharide is glucose in contents of $78 \%$, while among twenty natural amino acids, the major amino acids involved are aspartic acid, glycine, glutamic acid, alanine, serine and threonine in contents of $13,11,10,9,9$ and 8 , respectively. The viscosityaveraged molecular weight of FYGL is $2.6 \times 10^{5}$. Although FYGL properties have been investigated, its antihyperglycaemic mechanism in vivo is still unclear and further research is necessary. In the present study, we used the C57BL/6 db/db mouse, which is a useful model of type 2 diabetes associated with dyslipidaemia ${ }^{(25)}$ and insulin resistance ${ }^{(26)}$ to evaluate pharmacological potencies of FYGL such as plasma glucose level, serum insulin concentration and lipid profiles in the serum and liver. In addition, the expression and activity of PTP1B, the levels of tyrosine phosphorylation of IR $\beta$-subunit and hepatic glycogen were also investigated to reveal antihyperglycaemic mechanisms of FYGL in vivo.

\section{Materials and methods}

\section{Materials and chemicals}

All the dried fruiting bodies of G. lucidum were purchased from Shanghai Leiyunshang Pharmaceutical Company Limited. The kit for the analysis of insulin was purchased from Beifang Biotech Research Center. The kits for the analysis of TAG, total cholesterol (TC), LDL-cholesterol (LDL-C), HDL-cholesterol (HDL-C), NEFA and hepatic glycogen were purchased from Nanjing Jianchen Bioengineering Institute. Metformin, bovine serum albumin, porcine insulin, $p$-nitrophenyl phosphate, Tris, Nonidet P-40 and nitrocellulose (NC) membranes were purchased from Sigma Chemical Company. The reagents for SDS-PAGE and immunoblotting experiments were purchased from BioVision and the necessary apparatus from Bio-Rad. Protein A-Sepharose was from Pharmacia. $\alpha$-PTP1B polyclonal antibody, rabbit polyclonal anti-IR $\beta$-subunit antibody and monoclonal anti-phosphotyrosine antibody (PY99) were purchased from Santa Cruz Biotechnology, Inc. Anti-rabbit IgG (IgG) conjugated with horseradish peroxidase and enhanced chemiluminescence detection reagents were from GE, Inc. Bradford protein assay reagent was purchased from Bio-Rad. All other chemicals were of the highest analytical grade.

\section{Preparation of Fudan-Yueyang-Ganoderma lucidum from Ganoderma lucidum}

FYGL was extracted from the dried fruiting bodies of G. lucidum with optimised techniques as described in Fig. $1^{(24)}$. Briefly, $160 \mathrm{~g}$ dried fruiting bodies of G. lucidum were milled and then degreased with 2 litres of $95 \%$ boiling ethanol for $30 \mathrm{~min}$. The residues were dried and then decocted with stirring in 3 litres of boiling water for $2 \mathrm{~h}$. After filtration, the residues were treated with 2 litres of $2 \mathrm{M}-\mathrm{NH}_{3}$ aqueous solution at room 
Dried fruiting body of G. lucidum

$\downarrow 2$ litres boiling $95 \%$ ethanol for $30 \mathrm{~min}$

Residues

$\downarrow 3$ litres boiling water for $2 \mathrm{~h}$

Residues

2 litres of $2 \mathrm{M}-\mathrm{NH}_{3}$ aqueous solution at room

temperature for $24 \mathrm{~h}$

Alkali extract

Neutralised, concentrated and

$\checkmark$ filtered

Filtrate

Precipitated with ethanol in a volume ratio

$\downarrow$ of 1:5

Supernatant

Sephadex G75 column chromatography with

$2 \mathrm{M}-\mathrm{NaCl}$ solution as the eluent

\section{FYGL}

Fig. 1. Screening procedure of Fudan-Yueyang-Ganoderma lucidum (FYGL) from Ganoderma lucidum.

temperature for $24 \mathrm{~h}$, then the supernatant was neutralised by $2 \mathrm{M}$-acetic acid and then dialysed, concentrated and precipitated with $80 \%(\mathrm{v} / \mathrm{v})$ ethanol. The supernatant was subjected to Sephadex G75 column chromatography with $2 \mathrm{M}-\mathrm{NaCl}$ solution as the eluent. The eluates were collected and characterised by the phenol-sulphuric acid method with UV absorption at a wavelength of $490 \mathrm{~nm}$. In this analysis, three fractions were collected, and then dialysed and lyophilised. The fraction having the best PTP1B inhibition was named as FYGL. The yield of $F Y G L$ is about $0.96 \%$ from raw material and the purity of $F Y G L$ obtained is $91 \%$ measured by gel permeation chromatography with double detectors of UV $(\lambda=254 \mathrm{~nm})$ and refractive index.

\section{In vivo experimental design}

A total of ten $\mathrm{C} 57 \mathrm{BL} / 6$ mice and twenty-eight type 2 diabetic C57BL/ $6 d b / d b$ mice (male, 5-8 weeks old) were bought from Shanghai Institute of Materia Medica, Chinese Academy of Sciences. All animal trial procedures instituted by the Ethical Committee for the Experimental Use of Animals and for Drug Safety Evaluation in Shanghai University of Traditional Chinese Medicine were followed. The ten $\mathrm{C} 57 \mathrm{BL} / 6$ mice were set as group I, normal mice. The twenty-eight type 2 diabetic $d b / d b$ mice were divided into four groups: group II, diabetic control mice; group III, diabetic mice treated with $75 \mathrm{mg} / \mathrm{kg}$ low dose of FYGL; group IV, diabetic mice treated with $225 \mathrm{mg} / \mathrm{kg}$ high dose of FYGL; group V, diabetic mice treated with $200 \mathrm{mg} / \mathrm{kg}$ dose of metformin. The mice were distributed based on the mean initial blood glucose levels within the four diabetic groups. All drugs were dissolved in $0.9 \%$ saline and administered intragastrically for 4 weeks. During the experimental period, the body weight and blood glucose of $12 \mathrm{~h}$ fasted mice were measured every week. The dosage was adjusted every week according to any change in body weight to maintain a similar dose per $\mathrm{kg}$ of mice over the entire period of study for each group.

At the end of the treatment, mice were fasted overnight, anaesthetised and killed by cervical decapitation. Before killing, all the animals were administered intraperitoneally with insulin ( $3 \mathrm{U} / \mathrm{kg}$ in saline with $0 \cdot 1 \%$ bovine serum albumin). After killing, the liver, soleus muscle and adipose tissue were also immediately removed from all the animals in $10 \mathrm{~min}$ after the insulin injection and quickly frozen in liquid $\mathrm{N}_{2}$, and then the tissues were stored in a freezer at $-70^{\circ} \mathrm{C}$ for analysis. In the present study, all procedures used for animal trials were in accordance with the Regulations of Experimental Animal Administration issued by State Committee of Science and Technology of the People's Republic of China on 14 November 1988. The study was approved (no. SYXK (Shanghai) 20090065; SCXK (Shanghai) 2007-0005) by the Ethical Committee on Animal Experimentation in the Shanghai University of Traditional Chinese Medicine.

\section{Measurements of plasma glucose and insulin levels}

Plasma samples were obtained from the tail vein $2 \mathrm{~h}$ before the oral administration of the drugs every week for plasma glucose analysis. The glucose level in the plasma was measured using the glucose oxidase method (sensitivity of $0 \cdot 1 \mathrm{~mm}$; Sigma Diagnostics). The final fasting plasma samples were obtained by celiac puncture under halothane anaesthesia before mice were killed, and then centrifuged $(3000 \mathrm{~g}, 15 \mathrm{~min})$ at $4^{\circ} \mathrm{C}$ for the separation of serum insulin, which was measured by the RIA method.

\section{Lysate preparation and protein assay in vivo}

Briefly, $50 \mathrm{mg}$ of the frozen liver sample were homogenised in $2 \mathrm{ml}$ ice-cold lysis buffer containing $50 \mathrm{~mm}-\mathrm{N}$-2-hydroxyethylpiperazine- $\mathrm{N}$-2-ethanesulfonic acid (pH 7.4), 100 mm-sodium fluoride, $10 \mathrm{~mm}$-sodium pyrophosphate, $4 \mathrm{mm-EDTA}, 2 \mathrm{~mm}-$ sodium orthovanadate and $1 \%$ Triton X-100, and the homogenate was centrifuged $(12000 \mathrm{~g}, 15 \mathrm{~min})$ at $4^{\circ} \mathrm{C}$ to remove the insoluble material. Similarly, $50 \mathrm{mg}$ of the frozen muscle sample were homogenised in $50 \mathrm{mmol} / 1$ ice-cold HEPES buffer $(\mathrm{pH}$ 7.4) containing $150 \mathrm{~mm}-\mathrm{NaCl}, 10 \mathrm{~mm}$-sodium pyrophosphate, $2 \mathrm{~mm}-\mathrm{Na}_{3} \mathrm{VO}_{4}, 10 \mathrm{~mm}-\mathrm{NaF}, 2 \mathrm{~mm}$-edetic acid, $2 \mathrm{~mm}$-phenylmethylsulfonyl fluoride, $10 \mu \mathrm{m}$-leupeptin, $1 \%$ (v/v) Nonidet P40 and $10 \%(\mathrm{v} / \mathrm{v})$ glycerol, and the homogenate was centrifuged $(12000 \mathrm{~g}, 15 \mathrm{~min})$ at $4^{\circ} \mathrm{C}$. The supernatant homogenate from the trialed mice tissue was collected individually, and the protein concentration in the homogenate was measured with Bradford protein assay reagent, using bovine serum albumin as the standard.

\section{Western blotting for protein tyrosine phosphatase $1 B$ expression analysis in vivo}

Liver or muscle supernatant homogenate containing $20 \mu \mathrm{g}$ protein was run on SDS-PAGE (10\% gel) and transferred electrophoretically onto the NC membrane for $5 \mathrm{~h}$. The NC membrane was then blocked for $2 \mathrm{~h}$ at room temperature with the block solution provided in enhanced chemiluminescence kits. The NC membrane was incubated with anti- $\alpha$-PTP1B polyclonal antibody overnight at $4^{\circ} \mathrm{C}$, and then with antirabbit IgG conjugated with horseradish-peroxidase in block 
solution for $1 \mathrm{~h}$, and washed for $30 \mathrm{~min}$ with wash solution (provided in enhanced chemiluminescence kits). The immunoreactive lanes on the $\mathrm{NC}$ membrane were detected by the enhanced chemiluminescence method and digitalised by the Gel Documentation System. Each membrane was blotted with ten lanes, and two mice from the same group were analysed in two adjacent lanes in one NC membrane. In total there were four $\mathrm{NC}$ membranes for all trialed mice and the results are averaged by ten (for the normal group) or seven (for the other groups) mice data in one group.

The PTP1B expressions in adipose tissue were not analysed because not enough samples were obtained.

\section{Protein tyrosine phosphatase $1 B$ activity in vivo}

Briefly, $100 \mathrm{mg}$ of the frozen tissue sample were homogenised in $1 \mathrm{ml}$ ice-cold buffer containing $50 \mathrm{~mm}$-Tris and $150 \mathrm{~mm}-$ $\mathrm{NaCl}$, and the homogenates were centrifuged (12000 g, $15 \mathrm{~min}$ for liver, $20 \mathrm{~min}$ for muscle and $30 \mathrm{~min}$ for adipose tissue) at $4{ }^{\circ} \mathrm{C}$ to remove the insoluble material. The supernatant homogenate from the trialed mice tissue was collected individually, and the protein concentration in the homogenate was measured with Bradford protein assay reagent, using bovine serum albumin as the standard.

The assay protocol of PTP1B activity in the tissue homogenate followed the kit's instruction. Briefly, PTP1B activity was measured by adding $50 \mu \mathrm{l}$ of $1 \mathrm{~mm}$ - $p$-nitrophenyl phosphate ( $p$-nitrophenyl phosphate as the substrate) buffer solution (pH 8.0, containing $50 \mathrm{~mm}$-Tris and $150 \mathrm{~mm}-\mathrm{NaCl}$ ) into $50 \mu \mathrm{l}$ of tissue supernatant homogenate containing $20 \mu \mathrm{g}$ protein. After incubation for $30 \mathrm{~min}$ at $37^{\circ} \mathrm{C}$, the PTP1B enzyme reaction was terminated by the addition of $200 \mu \mathrm{l}$ of $3 \mathrm{M}-\mathrm{NaOH}$. The amount of $p$-nitrophenol produced was measured by UV absorption at a wavelength of $405 \mathrm{~nm}$ with a microplate reader.

\section{Tyrosine phosphorylation level of insulin receptor $\beta$-subunit in vivo}

Liver or muscle supernatant homogenate containing $1 \mathrm{mg}$ protein was immunoprecipitated overnight with $2 \mu \mathrm{g}$ anti-IR $\beta$-subunit antibody coupled to protein A-Sephrose at $4^{\circ} \mathrm{C}$. The immune complex was washed twice with PBS ( $\mathrm{pH} 7 \cdot 4$ ) containing $1 \%$ Nonidet $\mathrm{P}-40$ and $2 \mathrm{~mm}-\mathrm{Na}_{3} \mathrm{VO}_{4}$, and resuspended in Laemmli buffer, and boiled for $5 \mathrm{~min}$. The protein was quantified and run on SDS-PAGE (10\% gel), and then electrotransferred from the gel to the NC membrane. The NC membrane was incubated with $1 \mathrm{mg} / 1 \mathrm{PY} 99$ overnight at $4^{\circ} \mathrm{C}$. The following steps were performed as described in the section 'Western blotting for PTP1B expression analysis in vivo'.

The tyrosine phosphorylation levels of the IR $\beta$-subunit in adipose tissue were also not analysed because not enough samples were obtained.

\section{Measurement of the lipid profile in the serum}

Plasma samples for lipid profile analysis were obtained from mice killed at the end of the treatment. TAG, TC, LDL-C and
HDL-C levels in the serum were measured following the commercial kit's instructions.

\section{Assay of the lipid profile and glycogen in the liver}

Briefly, $100 \mathrm{mg}$ of the frozen liver sample were homogenised in $1 \mathrm{ml}$ of $0.9 \%$ saline and shaken for $30 \mathrm{~min}$ at $4^{\circ} \mathrm{C}$. The homogenate was centrifuged $(12000 \mathrm{~g})$ for $15 \mathrm{~min}$ at $4^{\circ} \mathrm{C}$ and total lipids of the liver homogenates were extracted with a mixture of chloroform and methanol $(2: 1, \mathrm{v} / \mathrm{v})$ on the basis of the method of Folch et al. ${ }^{(27)}$, and the supernatant homogenate was collected. NEFA, TAG and TC levels in the liver were measured according to the commercial kit's instructions.

Then, $50 \mathrm{mg}$ of the frozen liver sample were digested in $500 \mu \mathrm{l}$ of $30 \% \mathrm{KOH}$ in boiling water for $15 \mathrm{~min}$, and then glycogen in the liver was measured following the commercial kit's instructions.

The lipid profile and glycogen in the skeletal muscle were not analysed because not enough samples were obtained.

\section{Statistical analysis}

Data are expressed as means with their standard errors. The statistical differences between the mean values in the two groups were analysed by Student's $t$ test and one-way ANOVA using Origin 7 Software (MicroCal Software). A $P$ value less than 0.05 or 0.01 is considered as a significant or very significant difference between the means.

\section{Results}

Plasma glucose levels, homeostasis model assessment of insulin resistance and insulin concentration in vivo

The antihyperglycaemic potency of FYGL showed dose-dependency against diabetic control mice, as shown in Fig. 2. The results of the drug treatments for 4 weeks are summarised in Table 1. As can be observed from Table 1, the fasting plasma glucose level was significantly higher $(P<0 \cdot 001)$ in diabetic control mice $(27.5$ (SEM 2.8$) \mathrm{mmol} / \mathrm{l})$ than in normal mice $(6.9$ (sem 0.4$) \mathrm{mmol} / \mathrm{l}$ ). The level of fasting plasma glucose in diabetic mice treated with a high dose of FYGL daily for 4 weeks was significantly decreased (19.5 (SEm $2 \cdot 1) \mathrm{mmol} / \mathrm{l}, P<0 \cdot 01)$, compared with diabetic control mice (27.5 (SEM 2.8) mmol/l) and metformin-treated mice (13.9 (SEM 1.4) mmol/l) without any statistically significant difference.

It was also noted that the homeostasis model assessment of insulin resistance (HOMA-IR) was significantly higher $(P<0.001)$ in diabetic control mice $(15.8$ (SEM 0.9)) than in normal mice (3.8 (SEM 0.3)), while homeostasis model assessment of $\beta$-cell function (HOMA- $\beta$ ) was significantly lower $(P<0.001)$ in diabetic control mice $(10.8$ (SEM 0.5)) than in normal mice (72.4 (SEM 1.6)). After the mice were treated with FYGL and metformin for 4 weeks, serum insulin concentration and HOMA-IR were significantly lower in diabetic mice treated with a high dose of FYGL (9.7 (SEM 1.0) $\mu \mathrm{IU} / \mathrm{ml}, P<0.05$ and 8.4 (sem 0.9), $P<0 \cdot 01$, respectively) than in diabetic control mice (13.0 (SEM 0.7) $\mu \mathrm{IU} / \mathrm{ml}$ and 15.0 (SEM 1.5 ), respectively) while 


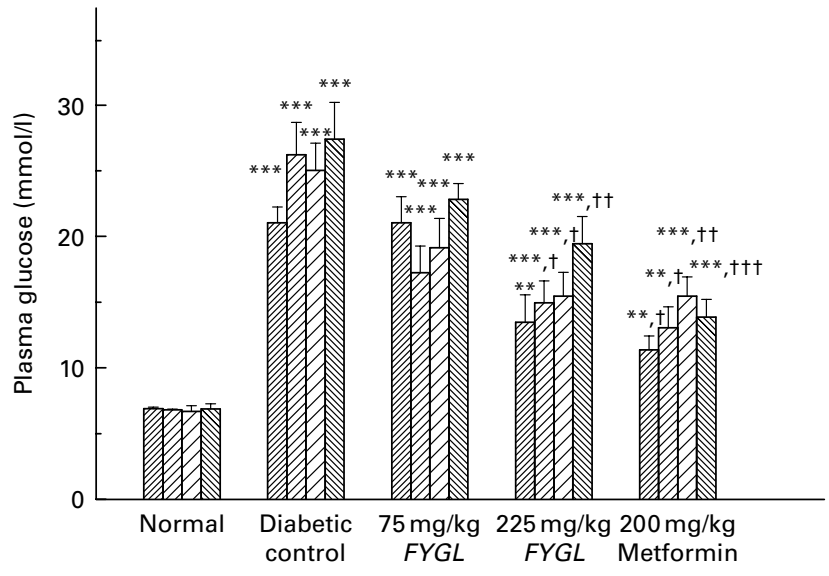

Fig. 2. Potencies of Fudan-Yueyang-Ganoderma lucidum (FYGL) and metformin on plasma glucose in vivo. The drugs were administered orally once per $d$ for 4 weeks. Values are means, with their standard errors represented by vertical bars. The statistical differences between the mean values in the two groups were analysed by one-way ANOVA. Mean values were significantly different from those of the normal group: ${ }^{\star *} P<0.01,{ }^{\star \star *} P<0.001$. Mean values were significantly different from those of the diabetic control group: $† P<0.05$, †† $P<0.01$, ††† $P<0.001$. $\mathbb{Z}, 1$ Week; $\square, 2$ weeks; $\square$ 3 weeks; $\mathbb{\mathbb { N } ,} 4$ weeks.

FYGL had no effect on HOMA- $\beta$. HOMA-IR (9.3 (SEM 0.9), $P<0 \cdot 001)$ in metformin-treated diabetic mice was significantly reduced and HOMA- $\beta$ (28.8 (SEM 1.2)) was significantly higher $(P<0 \cdot 001)$ than that in diabetic control mice (10.8 (SEM 0.5)). In addition, there was no significant difference in the final body weight and body-weight growth trend among the diabetic control mice and the FYGL- and metformin-treated diabetic mice (see Table 1 and Fig. 3).

Effects of Fudan-Yueyang-Ganoderma lucidum on protein tyrosine phosphatase $1 B$ expression in the liver and skeletal muscle

PTP1B content in the tissues of normal mice is referred to as $100 \%$. As can be seen from Fig. 4, PTP1B levels in the liver and skeletal muscle of the diabetic control were increased by 21 and $62 \%(P<0 \cdot 01)$, respectively, compared with those of normal mice. In contrast, in diabetic mice treated with a high dose of $F Y G L$, the PTP1B level was significantly reduced by $34 \%(P<0.05)$ in the liver (Fig. 4(a) and $\left.\left(\mathrm{a}^{\prime}\right)\right)$ and $38 \%$ $(P<0.001)$ in the skeletal muscle (Fig. 4(b) and $\left.\left(b^{\prime}\right)\right)$, compared with that of diabetic control mice, but metformin had no significant effect on the PTP1B content in the tissues.

Effects of Fudan-Yueyang-Ganoderma lucidum on protein tyrosine phosphatase 1B activity in the liver, muscle and adipose tissue

PTP1B activity in the tissues of normal mice is referred to as $100 \%$. It can be observed from Fig. 5 that PTP1B activities in the liver, skeletal muscle and adipose tissue of the diabetic control were increased by $47 \%$ (Fig. 5(a)), 25\% (Fig. 5(b)) and 50\% (Fig. 5(c)), respectively, compared with that in the normal group. When diabetic mice were treated with a high dose of FYGL, PTP1B activities were significantly decreased by $49 \%$ in the liver (Fig. 5(a)), 55\% $(P<0.01)$ in the skeletal muscle (Fig. 5(b)) and 19\% in the adipose tissue (Fig. 5(c)), compared with that in the diabetic control. It was found that FYGL shows a dose-dependency against PTP1B activity in the tissues of $\mathrm{db}$ / $d b$ mice. The $200 \mathrm{mg} / \mathrm{kg}$ dose of metformin reduces PTP1B activity in the liver and skeletal muscle while no effect was found on PTP1B activity in the adipose tissue of diabetic mice.

\section{Effects of Fudan-Yueyang-Ganoderma lucidum on the relative active ratio of protein tyrosine phosphatase $1 B$ in the liver and skeletal muscle}

When considering the active ratio of PTP1B which is calculated by PTP1B activity over the PTP1B expression, we found that $225 \mathrm{mg} / \mathrm{kg} F Y G L$ significantly decreased the relative active ratio of PTP1B by $22 \%(P<0.01)$ in the liver (Fig. 6(a)) and $41 \%(P<0 \cdot 01)$ in the skeletal muscle (Fig. 6(b)), compared with that in the diabetic control.

Table 1. Characteristics of the trialed animals after 4 weeks of drug treatmentsł (Mean values with their standard errors)

\begin{tabular}{|c|c|c|c|c|c|c|c|c|c|c|c|c|}
\hline \multirow[b]{2}{*}{ Groups } & \multicolumn{2}{|c|}{$\begin{array}{l}\text { Plasma glucose } \\
(\mathrm{mmol} / \mathrm{l})\end{array}$} & \multicolumn{2}{|c|}{$\begin{array}{c}\text { Insulin } \\
(\mu \mid \mathrm{U} / \mathrm{ml})\end{array}$} & \multicolumn{2}{|c|}{$\begin{array}{l}\text { Initial body } \\
\text { weight (g) }\end{array}$} & \multicolumn{2}{|c|}{$\begin{array}{l}\text { Final body } \\
\text { weight (g) }\end{array}$} & \multicolumn{2}{|c|}{ HOMA-IR§ } & \multicolumn{2}{|c|}{ HOMA- $\beta \|$} \\
\hline & Mean & SEM & Mean & SEM & Mean & SEM & Mean & SEM & Mean & SEM & Mean & SEM \\
\hline Normal & $6 \cdot 9$ & 0.4 & $12 \cdot 3$ & $1 \cdot 1$ & $27 \cdot 0$ & 1.4 & $30 \cdot 4$ & 0.7 & $3 \cdot 8$ & 0.3 & $72 \cdot 4$ & $1 \cdot 6$ \\
\hline Diabetic control & $27 \cdot 5^{\star \star \star}$ & $2 \cdot 8$ & $13 \cdot 0$ & 0.7 & $26 \cdot 9$ & 1.0 & 34.8 & $1 \cdot 2$ & $15 \cdot 8^{\star \star *}$ & 0.9 & $10 \cdot 8^{\star \star \star}$ & 0.5 \\
\hline $75 \mathrm{mg} / \mathrm{kg} F Y G L$ & $22 \cdot 9^{\star \star \star}$ & $1 \cdot 2$ & $11 \cdot 7$ & $1 \cdot 2$ & $26 \cdot 9$ & $1 \cdot 0$ & 34.5 & $1 \cdot 2$ & $11 \cdot 9^{\star \star \star}$ & $1 \cdot 2$ & $12 \cdot 1^{\star \star \star}$ & 0.5 \\
\hline $225 \mathrm{mg} / \mathrm{kg} F Y G L$ & $19 \cdot 5^{\star \star \star} \dagger †$ & $2 \cdot 1$ & $9 \cdot 7 \dagger$ & $1 \cdot 0$ & $26 \cdot 7$ & $1 \cdot 7$ & $35 \cdot 3$ & $1 \cdot 2$ & $8 \cdot 4^{\star * \star} \dagger † \dagger$ & 0.9 & $12 \cdot 1^{\star \star \star}$ & 0.6 \\
\hline $200 \mathrm{mg} / \mathrm{kg}$ Metformin & $13 \cdot 9^{\star * \star}+† \dagger$ & 1.4 & $15 \cdot 0$ & 1.5 & $26 \cdot 1$ & 1.5 & $37 \cdot 8$ & $1 \cdot 2$ & $9 \cdot 3^{\star \star \star} † \dagger †$ & 0.9 & $28 \cdot 8^{* * \star}+† \dagger$ & $1 \cdot 2$ \\
\hline
\end{tabular}

HOMA-IR, homeostasis model assessment of insulin resistance; HOMA- $\beta$, homeostasis model assessment of $\beta$-cell function; FYGL, Fudan-Yueyang-Ganoderma lucidum.

${ }^{\star \star \star}$ Mean values were significantly different from those of the normal group $(P<0.001)$.

Mean values were significantly different from those of the diabetic control group: $\uparrow P<0.05, \uparrow \dagger P<0.01, \dagger \dagger \uparrow P<0.001$.

$\ddagger$ The statistical differences between the mean values in the two groups were analysed by Student's $t$ test and one-way ANOVA.

$\S$ HOMA-IR $=($ plasma insulin level $(\mu \mathrm{lU} / \mathrm{ml}) \times$ plasma glucose level $(\mathrm{mmol} / \mathrm{l})) / 22.5$.

$\|$ HOMA- $\beta=(20 \times$ plasma insulin level $(\mu \mathrm{lU} / \mathrm{ml})) /($ plasma glucose level $(\mathrm{mmol} / \mathrm{l})-3 \cdot 5)$. 


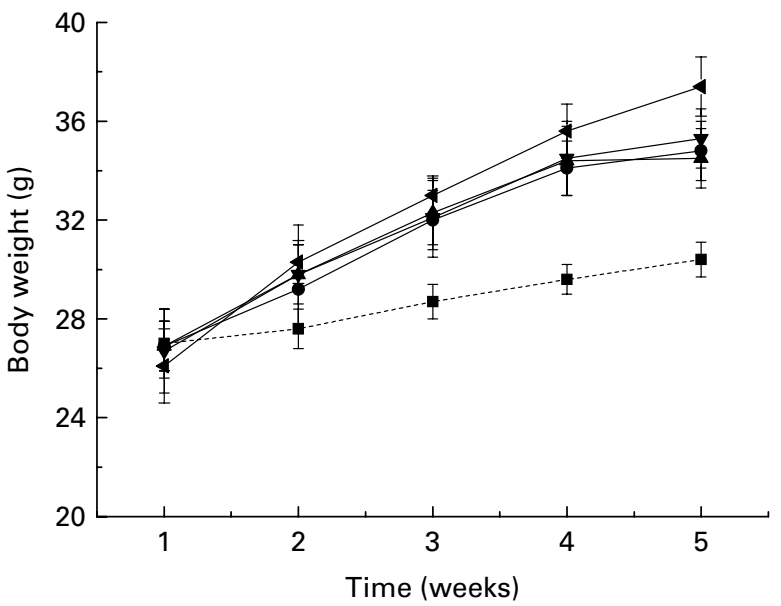

Fig. 3. Potencies of Fudan-Yueyang-Ganoderma lucidum (FYGL) and metformin on body weight in vivo. The drugs were administered orally once per $d$ for 4 weeks. Values are means, with their standard errors represented by vertical bars. ....., Normal; $\multimap-$, diabetic control; $\multimap$, $75 \mathrm{mg} / \mathrm{kg}$ FYGL; $\rightarrow$, $225 \mathrm{mg} / \mathrm{kg}$ FYGL; —, $225 \mathrm{mg} / \mathrm{kg}$ metformin.

\section{Effects of Fudan-Yueyang-Ganoderma lucidum on the} tyrosine phosphorylation level of the insulin receptor $\beta$ subunit in the liver and skeletal muscle

The tyrosine phosphorylation level of the IR $\beta$-subunit in normal mice is referred to as $100 \%$. It was observed that the tyrosine phosphorylation levels of the IR $\beta$-subunit in the diabetic control were $89 \%$ in the liver (Fig. $7(\mathrm{a})$ and $\left(\mathrm{a}^{\prime}\right)$ ) after stimulation with insulin. The tyrosine phosphorylation level $(129 \%)$ in the liver of diabetic mice treated with a high dose of $F Y G L$ was significantly higher $(P<0.05)$ than that $(89 \%)$ of

(a)
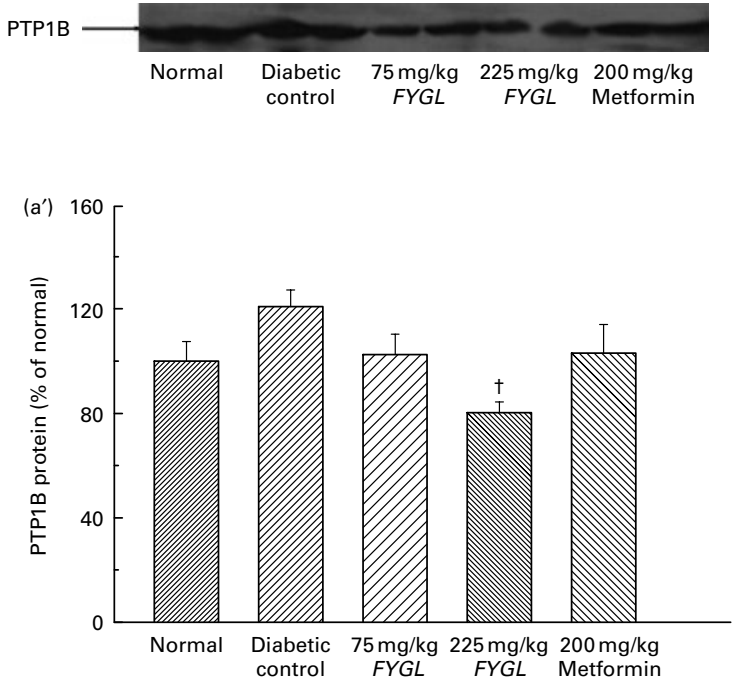

control mice, as shown in Fig. 7(a) and ( $\left.a^{\prime}\right)$. Similarly, the tyrosine phosphorylation level $(130 \%)$ in the skeletal muscle of mice treated with a high dose of $F Y G L$ was significantly higher $(P<0.01)$ than that $(82 \%)$ of control mice, as shown in Fig. 7(b) and $\left(\mathrm{b}^{\prime}\right)$. The effect of $F Y G L$ on the tyrosine phosphorylation level of the IR $\beta$-subunit in vivo was dose-dependent; in contrast, metformin had no effect on the tyrosine phosphorylation level of the IR $\beta$-subunit in vivo.

\section{Effects of Fudan-Yueyang-Ganoderma lucidum on the serum lipid profile in vivo}

The effects of the drugs including FYGL and metformin on the serum lipid profile in vivo after 4 weeks of treatment are summarised in Table 2. The TAG, TC, LDL-C and HDL-C levels were significantly decreased by 52.8\% $(P<0.01), \quad 65.9 \%$ $(P<0.001), 75.2 \%(P<0.001)$ and $41.7 \%(P<0.05)$, respectively, in $d b / d b$ diabetic mice treated with a high dose of FYGL, compared with those for the diabetic control, and the potency of FYGL was dose-dependent. However, metformin had no obvious effect on the serum lipid profiles of $d b / d b$ diabetic mice.

\section{Effects of Fudan-Yueyang-Ganoderma lucidum on the lipid profile and glycogen in the liver}

The effects of the drug treatments on the lipid profile and glycogen in the liver are summarised in Table 3. As can be observed from Table 3, the TAG, TC, NEFA and glycogen levels in the liver were significantly increased $(P<0.05)$ in diabetic control mice, compared with that in normal mice. After 4 weeks, the TAG, TC and NEFA levels were significantly decreased by $65.6 \%$ $(P<0.001), 60.7 \%(P<0.001)$ and $31.5 \%(P<0.05)$, respectively, while the hepatic glycogen level was significantly (b)
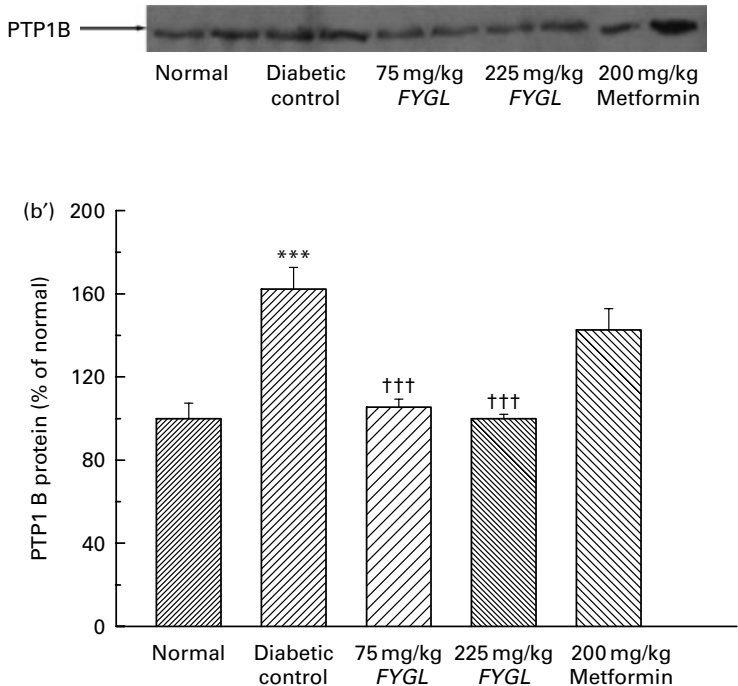

Fig. 4. Effects of Fudan-Yueyang-Ganoderma lucidum (FYGL) and metformin on protein tyrosine phosphatase 1B (PTP1B) expression in (a, $\left.a^{\prime}\right)$ the liver and (b, $\left.b^{\prime}\right)$ skeletal muscle. Values are means, with their standard errors represented by vertical bars, in the normal group referred to as $100 \%$. The statistical differences between the mean values in the two groups were analysed by one-way ANOVA. Mean values were significantly different from those of the normal group: ${ }^{* \star *} P<0.001$. Mean values were significantly different from those of the diabetic control group: $\dagger P<0.05, \mathrm{t} \dagger P<0.001$. The images (a) and (b) on the nitrocellulose (NC) membranes represent the results of the analysis of the liver and skeletal muscle, respectively, on one of four NC membranes. 

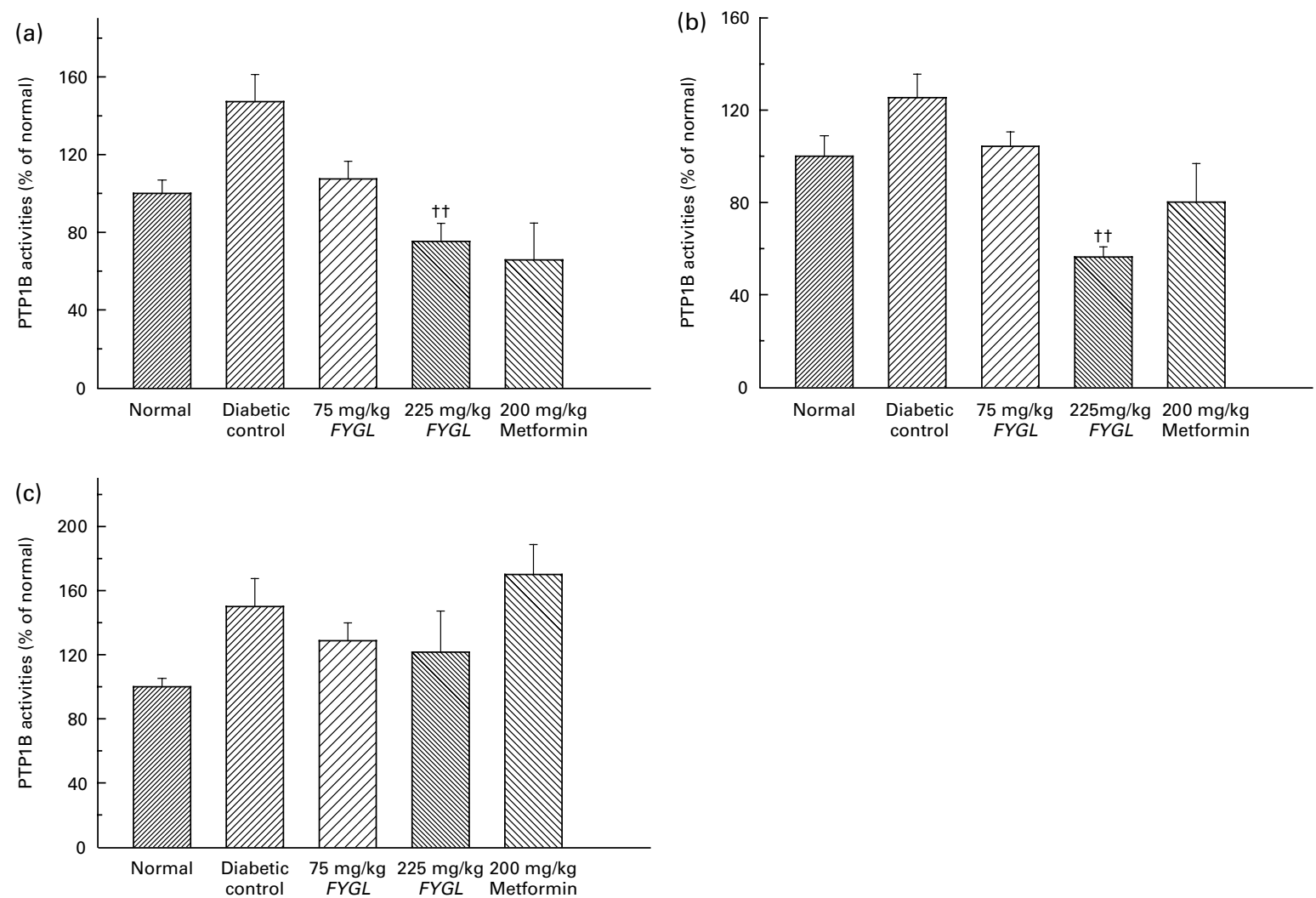

Fig. 5. Effects of Fudan-Yueyang-Ganoderma lucidum (FYGL) and metformin on protein tyrosine phosphatase 1B (PTP1B) activities in (a) liver, (b) skeletal muscle and (c) adipose tissue. Values are means, with their standard errors represented by vertical bars, in the normal group referred to as $100 \%$. The statistical differences between the mean values in the two groups were analysed by one-way ANOVA. Mean values were significantly different from those of the diabetic control group: $\dagger+P<0.01$.

increased by $109 \cdot 6 \%(P<0 \cdot 001)$ in diabetic mice treated with a high dose of FYGL, compared with that of the diabetic control, and the potency of FYGL was dose-dependent. It was also observed that the TAG and hepatic glycogen levels were decreased by $60 \cdot 2 \%(P<0 \cdot 001)$ and $19 \cdot 1 \%$, respectively, while the TC and NEFA levels were increased by 21.4 and $8.2 \%$, respectively, in metformin-treated diabetic mice, compared with those of the diabetic control.

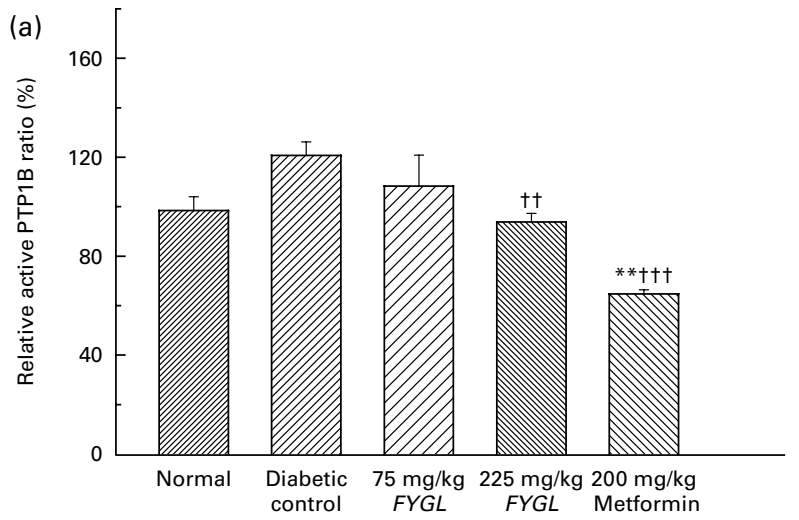

\section{Discussion}

Type 2 diabetes is a metabolic disorder characterised by insulin resistance, hyperglycaemia and dyslipidaemia. PTP1B is a $50 \mathrm{kDa}$ cytosolic tyrosine dephosphorylase consisting of 435 amino acids that is widely expressed in human organs ${ }^{(28)}$. It is well known that PTP1B dephosphorylates both the phosphorylated IR $\beta$-subunit and the phosphorylated IRS to regulate negatively the insulin signal transmission ${ }^{(9)}$. PTP1B inhibitors can be

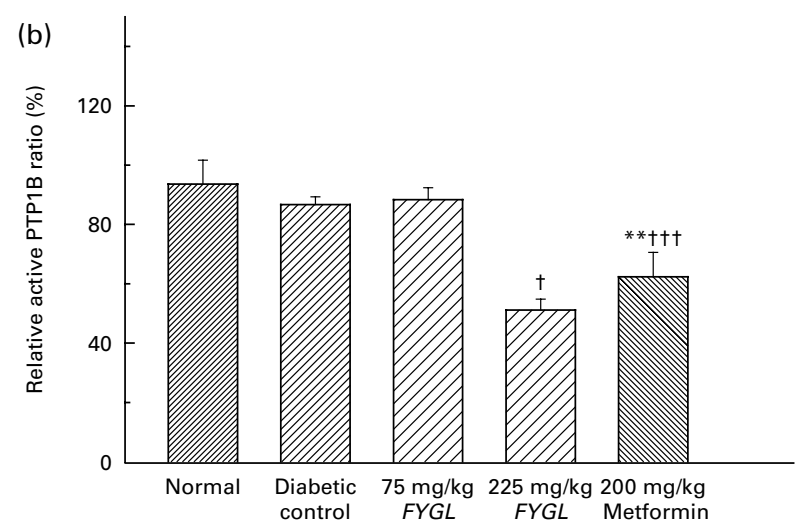

Fig. 6. Effects of Fudan-Yueyang-Ganoderma lucidum (FYGL) and metformin on the relative active ratio of protein tyrosine phosphatase 1B (PTP1B) in (a) the liver and (b) skeletal muscle. Values are means, with their standard errors represented by vertical bars. The statistical differences between the mean values in the two groups were analysed by one-way ANOVA. Mean values were significantly different from those of the normal group: ${ }^{\star \star} P<0 \cdot 01$. Mean values were significantly different from those of the diabetic control group: $\uparrow P<0.05$, $\uparrow+P<0.01$, $\uparrow \uparrow \uparrow P<0.001$. 
(a)

$\operatorname{IR} \beta$

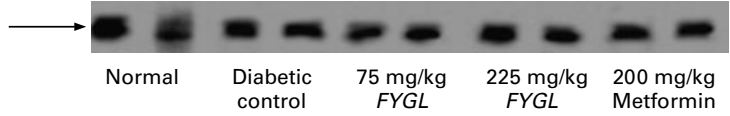

$\left(a^{\prime}\right)$

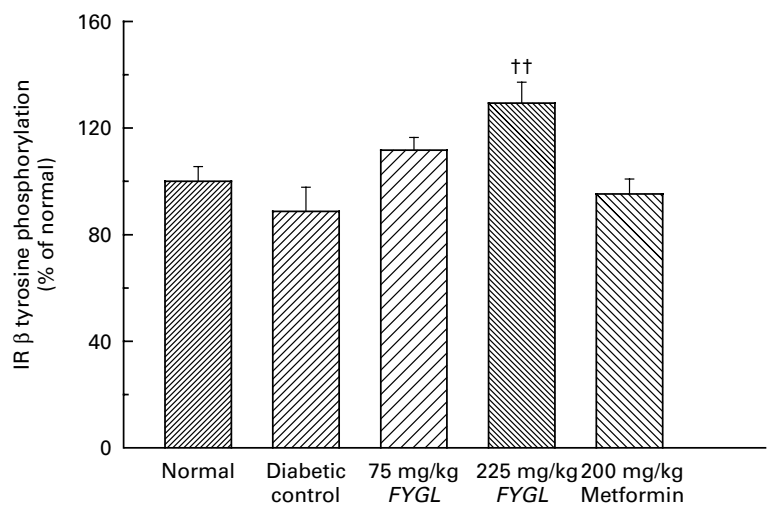

(b)

IR $\beta$

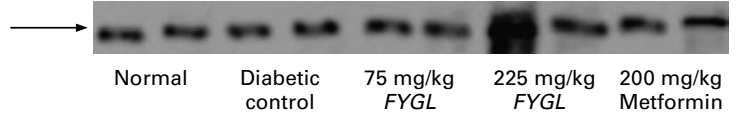

$\left(b^{\prime}\right)$

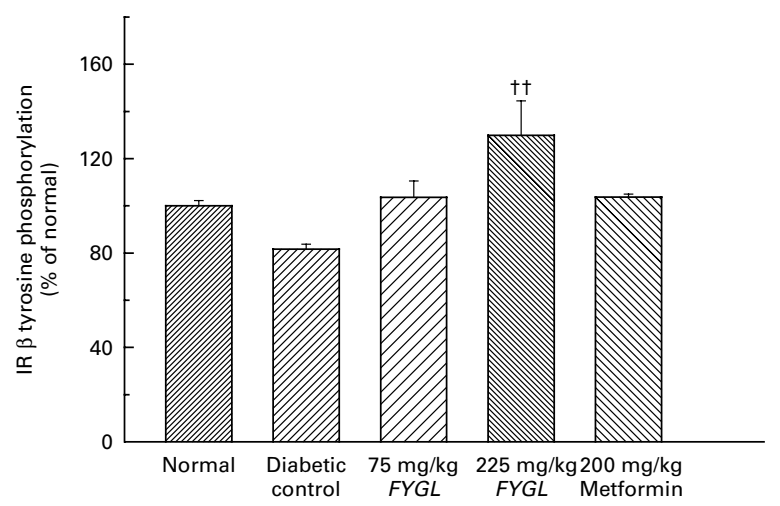

Fig. 7. Effects of Fudan-Yueyang-Ganoderma lucidum (FYGL) and metformin on the insulin-stimulated tyrosine phosphorylation levels of insulin receptor (IR) $\beta$ subunit in (a) the liver and (b) skeletal muscle. The quantitative analysis of the relative IR $\beta$-subunit tyrosine phosphorylation levels in $\left(a^{\prime}\right)$ the liver and $\left(b^{\prime}\right)$ skeletal muscle of drug-treated mice is referred to that of the insulin-stimulated normal mice. Values are means, with their standard errors represented by vertical bars, in the normal group referred to as $100 \%$. The statistical differences between the mean values in the two groups were analysed by one-way ANOVA. Mean values were significantly different from those of the diabetic control group: $\dagger P<0.05, \dagger \dagger P<0.01$. The images (a) and (b) on the nitrocellulose (NC) membranes represent the results of the analysis of the liver and skeletal muscle, respectively, on one of four NC membranes.

divided into two types: competitive inhibitors and non-competitive inhibitors. Most of the small-molecule competitive inhibitors mimic the phosphorylated tyrosine IR, while most of the non-competitive inhibitors act via oxidation of the catalytic cysteine Cys 215 or by preventing the closure of the WPD loop ${ }^{(29)}$. Unfortunately, most of the small-molecule inhibitors fail to succeed in vivo. To date, finding a selective smallmolecule phosphatase inhibitor with good cell permeability and oral bioavailability in vivo is difficult mainly due to the highly polar phosphatase active site and the shallowness of the surrounding protein surface, which do not allow for the productive bindings of the typical lipophilic membrane with the permeable small-molecule phosphatase inhibitor ${ }^{(15,16)}$. Significantly, FYGL, a water-soluble macromolecular proteoglycan ${ }^{(24)}$ different from those small-molecule PTP1B inhibitors, does successfully inhibit the PTP1B activity and decrease the plasma glucose in vivo.

\section{Possible interaction sites of protein tyrosine phosphatase $1 B$ with Fudan-Yueyang-Ganoderma lucidum}

There exist various interactions between PTP1B and its inhibitors. Seiner et $a l .{ }^{(30)}$ found an acrolein PTP1B inhibitor binding to PTP1B via the conjugation of the carbon-carbon double bond of acrolein to the catalytic cysteine residue. Liu et al. ${ }^{(31)}$ reported a PTP1B analogue of 6-(phosphonodifluoromethyl)2-naphthoic acid binding to PTP1B with its 2-carboxyl group through a bridge of a water molecule. Liu et al. ${ }^{(32)}$ designed a bidentate PTP1B inhibitor called SNA. The authors proposed that electrostatic interactions are more likely to be present between PTP1B and SNA than van der Waals interactions, and

Table 2. Effects of the drugs on the serum lipid profile in vivo after 4 weeks of treatmentł (Mean values with their standard errors)

\begin{tabular}{|c|c|c|c|c|c|c|c|c|}
\hline \multirow[b]{2}{*}{ Groups } & \multicolumn{2}{|c|}{ TAG $(\mathrm{mmol} / \mathrm{l})$} & \multicolumn{2}{|c|}{$\mathrm{TC}(\mathrm{mmol} / \mathrm{l})$} & \multicolumn{2}{|c|}{ LDL-C (mmol/l) } & \multicolumn{2}{|c|}{$\begin{array}{l}\mathrm{HDL}-\mathrm{C} \\
(\mathrm{mmol} / \mathrm{l})\end{array}$} \\
\hline & Mean & SEM & Mean & SEM & Mean & SEM & Mean & SEM \\
\hline Normal & 0.45 & 0.02 & 0.76 & 0.12 & 0.43 & 0.02 & 0.35 & 0.05 \\
\hline Diabetic control & $1.44^{\star \star \star}$ & 0.17 & $1.73^{\star \star \star}$ & 0.07 & $1.01^{\star \star \star}$ & 0.11 & 0.48 & 0.07 \\
\hline $75 \mathrm{mg} / \mathrm{kg} F Y G L$ & $1 \cdot 35^{\star \star \star}$ & 0.18 & $1 \cdot 37^{\star \star \star}$ & 0.13 & $1 \cdot 00^{\star \star *}$ & 0.07 & 0.49 & 0.06 \\
\hline $225 \mathrm{mg} / \mathrm{kg} F Y G L$ & $0.68+\dagger$ & 0.13 & $0.59+\dagger \dagger$ & 0.07 & $0.25^{\star *}+\dagger \dagger$ & 0.05 & $0.28 \dagger$ & 0.02 \\
\hline $200 \mathrm{mg} / \mathrm{kg}$ Metformin & $1.68^{\star \star \star}$ & 0.10 & $1 \cdot 63^{\star \star \star}$ & 0.08 & $1.05^{\star \star \star}$ & 0.09 & 0.54 & 0.08 \\
\hline
\end{tabular}

TC, total cholesterol; LDL-C, LDL-cholesterol; HDL-C, HDL-cholesterol; FYGL, Fudan-Yueyang-Ganoderma lucidum. Mean values were significantly different from those of the normal group: ${ }^{\star \star} P<0.01,{ }^{\star \star \star} P<0.001$.

Mean values were significantly different from those of the diabetic control group: $\uparrow P<0.05, \dagger \dagger P<0.01, \dagger \dagger \uparrow P<0.001$.

$\ddagger$ The statistical differences between the mean values in the two groups were analysed by Student's $t$ test and one-way ANOVA. 
Table 3. Effects of the drugs on TAG, total cholesterol (TC) and NEFA levels in the liver and hepatic glycogen in vivo after 4 weeks of treatmentł

(Mean values with their standard errors)

\begin{tabular}{|c|c|c|c|c|c|c|c|c|}
\hline \multirow[b]{2}{*}{ Groups } & \multicolumn{2}{|c|}{ TAG $(\mathrm{mg} / \mathrm{g})$} & \multicolumn{2}{|c|}{$\mathrm{TC}(\mathrm{mg} / \mathrm{g})$} & \multicolumn{2}{|c|}{ NEFA $(\mu \mathrm{mol} / \mathrm{g})$} & \multicolumn{2}{|c|}{ Glycogen (\%॰) } \\
\hline & Mean & SEM & Mean & SEM & Mean & SEM & Mean & SEM \\
\hline Normal & 108.0 & 9.8 & $15 \cdot 7$ & 1.4 & $22 \cdot 9$ & 0.5 & $5 \cdot 3$ & 0.4 \\
\hline Diabetic control & $240 \cdot 4^{\star \star *}$ & $6 \cdot 8$ & $47 \cdot 4^{\star * \star}$ & $2 \cdot 4$ & $86 \cdot 9^{\star \star \star}$ & $6 \cdot 1$ & $9 \cdot 4^{* *}$ & 1.5 \\
\hline $75 \mathrm{mg} / \mathrm{kg} F Y G L$ & $115 \cdot 0 \dagger+\dagger$ & 8.6 & $40 \cdot 6^{\star \star \star}$ & 1.6 & $73 \cdot 4^{\star \star \star}$ & $7 \cdot 2$ & $18 \cdot 0^{\star \star \star}+\dagger \dagger$ & 0.3 \\
\hline $225 \mathrm{mg} / \mathrm{kg} F Y G L$ & $82 \cdot 4^{*}+\dagger \dagger$ & 4.9 & $20 \cdot 8 \dagger+\dagger$ & 1.4 & $59 \cdot 5^{\star \star \star} \dagger$ & $5 \cdot 0$ & $19 \cdot 7^{\star \star \star}+\dagger \dagger$ & 0.9 \\
\hline $200 \mathrm{mg} / \mathrm{kg}$ Metformin & $100 \cdot 8+\dagger \dagger$ & 18.4 & $57 \cdot 6^{\star \star \star}$ & $6 \cdot 3$ & $94 \cdot 0^{\star \star \star *}$ & $3 \cdot 2$ & $7 \cdot 6^{\star \star}$ & 0.4 \\
\hline
\end{tabular}

FYGL, Fudan-Yueyang-Ganoderma lucidum.

Mean values were significantly different from those of the normal group: ${ }^{\star} P<0.05,{ }^{\star \star} P<0.01,{ }^{* \star *} P<0.001$.

Mean values were significantly different from those of the diabetic control group: $\dagger P<0.05$, $\uparrow \dagger \dagger P<0.001$.

$\ddagger$ The statistical differences between the mean values in the two groups were analysed by Student's $t$ test and one-way ANOVA

amino acid residues of Lys41, Arg 47 and Asp48 play important roles in the determination of the SNA conformation, potency and selectivity. Asante-Appiah et al. ${ }^{(33)}$ designed a peptide PTP1B inhibitor, $N$-benzoyl-L-glutamyl-(4-phosphono-(difluoromethyl))-L-phenylalanine-(4-phosphono-(difluoro-methyl))L-phenylalanineamide (BzN-EJJ-amide). The crystal structure of PTP1B in the complex of PTP1B with BzN-EJJ-amide showed that the hydrogen bond between BzN-EJJ-amide and Asp48 in PTP1B is of particular significance.

FYGL is constructed covalently by protein and polysaccharide. Generally, proteoglycan is formed by the protein backbone and polysaccharide side chains ${ }^{(34)}$. The protein is linked with polysaccharide by either O-linkages or N-linkages. The biological activities of proteoglycan are controlled by the interactions of polysaccharide side chains with the surrounding proteins through secondary bonding ${ }^{(34)}$. Although proteoglycans are difficult to pass through the cell membranes, they could be dissociated by the glycosidase ${ }^{(35)}$ to enter through the cells. Actually, we found that FYGL can interact with glycosidase in vitro (data not shown), suggesting that FYGL could be hydrolysed by the glycosidase into polysaccharide and protein in the stomach and small intestine in vivo; consequently, the dissociated protein motifs in FYGL might enter into the plasma through pinocytosis in the terminal position of the small intestine and then interact with PTP1B to inhibit the PTP1B activity in the insulin target tissues in vivo.

The viscosity-averaged molecular weight of FYGL $\left(2.6 \times 10^{5}\right)$ is larger than the molecular weight of PTP1B ( $50 \mathrm{kDa})$. However, the molecular weight of the protein motif in FYGL might be about $44 \mathrm{kDa}$ evaluated on the protein:polysaccharide ratio of $17: 77$. On the other hand, the molecular weight of the PTP1B native substrate, IR $\beta$-subunit, is $95 \mathrm{kDa}$ compared with that of the protein motif of FYGL. Therefore, the protein motif of FYGL might possibly interact with PTP1B in vivo by hydrogen bonding between the carboxyl groups of aspartic acid and glutamic acid in FYGL and Tyr20, Arg24 and Arg254 in PTP1B active sites ${ }^{(36)}$, competing with the IR $\beta$-subunit. Glover \& Tracey ${ }^{(37)}$ designed an IR kinase (IRK), IRK1154, sulfotyrosine eight-amino-acid-residue peptide (Thr1154Arg1155 Asp1156Ile1157sTyr1158Glu1159Thr1160Asp1161), based on the residues 1154-1161 in the kinase domain A-loop. In the molecular dynamics simulations of a fully hydrated model, IRK1154 binds to PTP1B in an extended $\beta$-strand conformation that is twisted about sTyr1158 and Thr1160. The sulfotyrosine moiety of IRK1154 is buried within the phosphotyrosine recognition pocket and held in position by a number of hydrogen bonds and ion pairs formed with PTP1B active residues. This result was strongly supported by two-dimensional NMR spectroscopy and X-ray crystal structures of PTP1B and IRK ${ }^{(37)}$. A similar event was also found in an epidermal growth factorderived peptide ${ }^{(38)}$. In the present study, the protein motifs in FYGL might interact with PTP1B in a similar model such as IRK1154 in vivo. The detailed interaction mechanism of FYGL will be investigated in a further study.

Influence of Fudan-Yueyang-Ganoderma lucidum targeting on protein tyrosine phosphatase $1 B$ in the insulin signal transduction pathway

In the present study, we used the type 2 diabetic C57BL/6 db/db mouse model to evaluate the antihyperglycaemic potency of FYGL in vivo. Figs. 4 and 5 show an increase in PTP1B expression and activity. As can be seen from Fig. 7, there is a decrease in the tyrosine phosphorylation levels of the IR $\beta$-subunit in the liver and skeletal muscle of diabetic mice, implying the PTP1B role in diabetic $d b / d b$ mice. Similarly, Tagami et al. ${ }^{(39,40)}$ found that PTP1B activity was increased in the skeletal muscle and adipose tissue of Otsuka Long-Evans Tokushima fatty rats. Haj et $a l^{(41)}$ found that liver-specific overexpression of PTP1B showed insulin resistance not only in the liver but also in other tissues in PTP1B knockout mice. Accordingly, PTP1B plays an important role in diabetic mice. When PTP1B is activated, the insulin signalling transduction pathway is blocked and the metabolism of plasma glucose is disturbed, resulting in the increase in the plasma glucose level. The increase in the tyrosine phosphorylation level of the IR $\beta$-subunit in the liver and skeletal muscle of FYGL-treated diabetic mice indicates the improvement of insulin sensitivity.

To date, only a few small-molecule PTP1B inhibitors synthesised have been demonstrated to be potential for application. For instance, Fukuda et al. ${ }^{(42)}$ synthesised monosodium (\{[5-(1,1-dimethylethyl)thiazol-2-yl]methyl\}\{[(4-\{4-[4-(1propylbutyl)phenoxy]methyl\}phenl)thiazol-2-yl]methyl łamino) acetate (named JTT-551), a small-molecule PTP1B inhibitor, which shows a good selectivity against other PTP. JTT-551 can enhance IR phosphorylation in the liver and decrease the 
glucose level without any gain in body weight in both $o b / o b$ and $d b / d b$ mice. Also, there are some reports about natural PTP1B inhibitors. Wang et al. ${ }^{(43)}$ found an ethanol extract of Artemisia dracunculus L. (PMI 5011), which can decrease the blood glucose and insulin levels in $\mathrm{KK}-\mathrm{A}^{\mathrm{y}}$ mice through the inhibition of PTP1B activity in the skeletal muscle. Also, Astragalus polysaccharide exerts insulin-sensitised and antihyperglycaemic activities in type 2 diabetic rats through the inhibition of PTP1B in the liver ${ }^{(44)}$ and skeletal muscle ${ }^{(45)}$.

Therefore, we suggest that FYGL decreases the expression and activities of PTP1B in the insulin-sensitive tissues of the liver and skeletal muscle due to the reduction in both the expression and the relative active ratio, leading to the increase in the tyrosine phosphorylation level of the IR $\beta$-subunit and the improvement of insulin sensitivity. So far, no PTP1B inhibitor such as FYGL has been found to be effective in multi-tissues in vivo.

\section{Beneficial effects of Fudan-Yueyang-Ganoderma lucidum} on the serum glucose level and insulin sensitivity through the inhibition of protein tyrosine phosphatase $1 B$

As can be observed from Table 1, a high dose of FYGL decreases considerably the serum glucose levels of diabetic mice, while there are no significant differences in serum insulin concentration between the diabetic control mice and normal mice. In general, the serum glucose level is maintained within a very narrow range through the tightly coordinated secretion of insulin and glucagon in normal physiology ${ }^{(46)}$. Hyperglycaemia can be induced by the overexpression of glucagon because the development of hyperglycaemia is positively dependent on the glucagon:insulin ratio ${ }^{(26)}$. In addition, the serum insulin concentration and HOMA-IR are significantly lower in diabetic mice treated with a high dose of FYGL than those in control mice, while FYGL has no effect on HOMA- $\beta$. There are also some reports about synthetic and natural insulin sensitisers that can decrease both plasma insulin concentrations and HOMA-IR. For example, Kim et $a l^{(47)}$ reported that selective agonists of PPAR $\alpha / \gamma$, PAR-5359, reduced plasma insulin and HOMA-IR in high-fat diet-induced obese mice. Bhavsar et al. ${ }^{(48)}$ isolated saponins from Helicteres isora. Saponins can decrease serum insulin and enhance insulin sensitivity in C57BL/KsJ- $d b / d b$ mice through increasing the expressions of adipsin, PPAR $\gamma$ and GLUT4. These reports indicate that insulin resistance is associated with insulin signal transduction factors including PPAR, GLUT and PTP1B. Insulin sensitivity can be improved through either the inhibition of negative factors such as PTP1B or the activation of positive factors such as PPAR and GLUT. In the present study, the extent of the reduction in HOMA-IR $(47 \%)$ and the increase in the tyrosine phosphorylation level of the IR $\beta$-subunit ( $45 \%$ in the liver and $58 \%$ in the skeletal muscle) are identical with those of the decrease in PTP1B activities ( $49 \%$ in the liver and $55 \%$ in the skeletal muscle) in the insulin-sensitive tissues of FYGL-treated diabetic mice and diabetic control mice, therefore leading to a $29 \%$ reduction in plasma glucose. Accordingly, it has been supposed that FYGL improves insulin sensitivity in vivo through the inhibition of PTP1B in insulin-sensitive tissues. On the other hand, it has been found that HOMA-IR in metformin-treated $d b / d b$ mice is increased, and the serum insulin concentration and HOMA- $\beta$ are also higher than those in diabetic control mice, indicating that metformin can improve insulin sensitivity as well as insulin secretion. The results are identical with those reported by Matveyenko et $a l .{ }^{(49)}$ who found that metformin was capable of inhibiting pancreatic $\beta$-cell apoptosis and preserving $\beta$-cell function. It is generally known that metformin is an insulin secretagogue which is better than an insulin sensitiser. Nevertheless, it has been supposed that FYGL acts as an insulin sensitiser through the inhibition of PTP1B instead of an insulin secretagogue through the recovery of pancreatic $\beta$-cells in $d b$ / $d b$ diabetic mice.

\section{Effect of Fudan-Yueyang-Ganoderma lucidum on obesity, dyslipidaemia and glycogen synthesis}

As has also been observed from Table 1 and Fig. 3, there is no significant difference in the final body weight and bodyweight growth trend between the diabetic control mice and the FYGL-treated diabetic mice, indicating that FYGL would not result in overweight gain perhaps due to its decreasing effect on lipogenic enzyme activity such as fatty acid and glucose 6-phosphate dehydrogenase. The anti-obesity result is similar to that of those mono- and disalicylic acid derivatives which are potential PTP1B inhibitors as the anti-obesity drugs that suppress the weight gain by the inhibition of ІкВ kinase$\beta$ and PTP1B activity ${ }^{(50)}$.

For diabetic patients, hyperglycaemia is often accompanied with dyslipidaemia ${ }^{(51)}$, which increase TAG, TC, LDL-C and decrease HDL-C. These serum lipid profiles are important plasma biochemistry indices for metabolic disorders. Abnormal values of these indices result in a series of complications. From Table 2, we found that there are higher values for TAG, TC, LDL$\mathrm{C}$ and HDL-C in diabetic control mice, and Kobayashi et al. ${ }^{(25)}$ also observed that those indices increased in $d b / d b$ mice, but FYGL significantly reduced serum lipid profiles, and the reduction potency of FYGL on LDL-C, which is highly responsible for dyslipidaemia, is about 2-fold stronger than that on HDL-C, which is an anti-arteriosclerosis factor, leading to an efficient treatment for dyslipidaemia. Unlike $F Y G L$, metformin has no effect on those plasma biochemistry indices in vivo, indicating that the signal transduction pathway of metformin is different from that of $F Y G L$.

There are some extracts from natural plants that have also been reported to have an antihyperlipidaemic effect on serum in vivo. For instance, Tao et al. ${ }^{(52)}$ isolated a polyphenol from Balanophora polyandra Griff. The extract from Balanophora polyandra Griff ameliorated hyperlipidaemia through reversing the defect expressions of anti-IR $\beta$-subunit, IRS-1, PTP1B and acetyl-CoA carboxylase $\beta$ and increasing the phosphorylated AMP kinase. Therefore, dyslipidaemia can be ameliorated by the inhibition of PTP1B.

In addition, it has been observed from Table 3 that hepatic lipid profiles in the liver of diabetic control mice are several fold higher than those in normal mice, and decreased considerably by $F Y G L$, implying the presence of dyslipidaemia in the liver of diabetic control mice and the effect of FYGL on hyperlipidaemia. Similarly, some natural plant extracts have 
also been reported that are able to reduce hepatic lipid profiles in vivo. Yamabe et al. ${ }^{(53)}$ evaluated loganin, an iridoid glycoside from Corni fructus. Loganin $(100 \mathrm{mg} / \mathrm{kg})$ led to a marked decrease in glucose, TAG and TC levels in the liver of $d b / d b$ mice through the alleviation of oxidative stress and PPAR activation. Actually, we found that FYGL also possessed antioxidant potency (data not shown), implying that $F Y G L$ reduces hepatic lipid profiles via a multi-target mechanism including alleviation of oxidative stress and inhibition of PTP1B in $d b / d b$ mice.

Besides lipid profiles, hepatic glycogen level is also an important biochemistry index in the liver. The acceleration of hepatic glycogen synthesis is one of the factors for decreasing blood glucose. The elevation of hepatic glucokinase activity and insulin sensitivity could increase the utilisation of blood glucose for glycogen storage in the liver. Table 3 shows the effect of the drug treatments on hepatic glycogen. FYGL improves the hepatic glycogen content, maybe resulting from increasing the activity of glycogen synthase via PKB and glycogen synthase kinase-3 as well as decreasing the transcription of gluconeogenic enzymes via PI3K and PKB like PTP1B antisense oligonucleotides $^{(54)}$, therefore increasing glycogen synthesis.

\section{Conclusion}

In the present study, we demonstrated in vivo pharmacological profiles of $F Y G L$, which is a novel proteoglycan extract from the fruiting bodies of G. lucidum, and efficient in PTP1B inhibition. After 4 weeks of oral treatment in type 2 diabetic $d b / d b$ mice, FYGL could decrease considerably the plasma glucose values $(P<0 \cdot 01)$, serum insulin concentration and HOMA-IR $(P<0 \cdot 001)$, which in turn could decrease the TAG, TC, LDL-C and HDL-C levels in the serum as well as the TAG, TC and NEFA levels in the liver, indicating the improvement of hyperlipidaemia. The mechanism of plasma glucose lowered by FYGL is on the basis of inhibiting the PTP1B expression and activity, consequently regulating the tyrosine phosphorylation level of the IR $\beta$-subunit and the hepatic glycogen level. Thus, FYGL is a potential candidate for the treatment of diabetes mellitus and the accompanying metabolic disorders.

\section{Acknowledgements}

This study was supported by the Natural Science Foundation of China (no. 20673022 and 21074025), the Soft Science Program of Jing-An district in Shanghai (no. 2008RZ002), the Scientific Program of Shanghai Municipal Public Health Bureau (no. 2008220 and 2010231), the Science and Technology Innovation Program of STCSM (no. 11DZ1971802) and the Innovation Program of Shanghai Municipal Education Commission (no. 12ZZ009). C.-D. W., B.-S. T., D. P. and P. Z. designed and performed the study. J.-S. W. and L.-F. P. performed the animal trial including preparation of the diet. Y.-M. H., D. Z., Z.-H. F. and H.-J. Y. performed the Western blot analyses. All authors were involved in the preparation of the manuscript. The authors declare that there are no conflicts of interests.

\section{References}

1. Harris M \& Zimmet P (1997) Classification of diabetes mellitus and other categories of glucose intolerance. In International Textbook of Diabetes Mellitus, 2nd ed., pp. 9-23 [K Alberti, P Zimmet and R Defronzo, editors]. Chichester: John Wiley and Sons Limited.

2. Barr AJ, Ugochukwu E, Lee WH, et al. (2009) Large-scale structural analysis of the classical human protein tyrosine phosphatome. Cell 136, 352-363.

3. Valentino L \& Pierre J (2006) JAK/STAT signal transduction: regulators and implication in hematological malignancies. Biochem Pharmacol 71, 713-721.

4. Tonks NK, Diltz CD \& Fischer EH (1988) Purification of the major protein-tyrosine-phosphatases of human placenta. J Biol Chem 263, 6722-6730.

5. Goldstein BJ (2002) Protein-tyrosine phosphatase 1B (PTP1B): emerging targets for therapeutic intervention in type 2 diabetes and related states of insulin resistance. J Clin Endocr Metab 87, 2474-2480.

6. Seely BL, Staubs PA, Reichart DR, et al. (1996) Protein tyrosine phosphatase $1 \mathrm{~B}$ interacts with the activated insulin receptor. Diabetes 45, 1379-1385.

7. Zabolotny JM, Haj FG, Kim YB, et al. (2004) Transgenic overexpression of protein-tyrosine phosphatase $1 \mathrm{~B}$ in muscle causes insulin resistance, but overexpression with leukocyte antigen-related phosphatase does not additively impair insulin action. J Biol Chem 279, 24844-24851.

8. Cromlish WA, Tang M, Kyskan R, et al. (2006) PTP1B-dependent insulin receptor phosphorylation/residency in the endocytic recycling compartment of CHO-IR cells. Biochem Pharmacol 72, 1279-1292.

9. Asante-Appiah E \& Kennedy BP (2003) Protein tyrosine phosphatases: the quest for negative regulators of insulin action. Am J Physiol Endocrinol Metab 284, E663-E670.

10. Saltiel AR (1996) Diverse signaling pathways in the cellular actions of insulin. Am J Physiol Endocrinol Metab 270, E375-E385.

11. Ahmad F, Azevedo JJ, Cortright R, et al. (1997) Alterations in skeletal muscle protein-tyrosine phosphatase activity and expression in insulin-resistant human obesity and diabetes. J Clin Invest 100, 449-458.

12. Elchebly M, Payette P, Michaliszyn E, et al. (1999) Increased insulin sensitivity and obesity resistance in mice lacking the protein tyrosine phosphatase-1B gene. Science 283, 1544-1548.

13. Escriva F, Rodriguez AG, Millan EF, et al. (2010) PTP1B deficiency enhances liver growth during suckling by increasing the expression of insulin-like growth factor-I. J Cell Physiol 225, 214-222.

14. Van Huijsduijnen RH, Bombrun A \& Swinnen D (2002) Selecting protein tyrosine phosphatases as drug targets. Drug Discov Today 7, 1013-1019.

15. Park H, Bhattarai BR, Ham SW, et al. (2009) Structure-based virtual screening approach to identify novel classes of PTP1B inhibitors. Eur J Med Chem 44, 3280-3284.

16. Combs AP (2010) Recent advances in the discovery of competitive protein tyrosine phosphatase $1 \mathrm{~B}$ inhibitors for the treatment of diabetes, obesity, and cancer. J Med Chem 53, 2333-2344.

17. Wasser SP \& Weis AL (1999) Therapeutic effects of substances occurring in higher Basidiomycetes mushrooms: a modern perspective. Crit Rev Immunol 19, 65-96.

18. Wasser SP (2011) Current findings, future trends, and unsolved problems in studies of medicinal mushrooms. Appl Microbiol Biotechnol 89, 1323-1332. 
19. Seto SW, Lam TY, Tam HL, et al. (2009) Novel hypoglycemic effects of Ganoderma lucidum water-extracct in obese/diabetic $(+d b /+d b)$ mice. Phytomedicine 16, 426-436.

20. Meng GL, Zhu HY, Yang SL, et al. (2011) Attenuating effects of Ganoderma lucidum polysaccharides on myocardial collagen cross-linking relates to advanced glycation end product and antioxidant enzymes in high-fat-diet and streptozotocininduced diabetic rats. Carbohydr Polym 84, 180-185.

21. Yang BK, Jeong SC, Park JB, et al. (2001) Swimming endurance capacity of mice after administration of exo-polymer produced from submerged mycelia culture of Ganoderma lucidum. J Microbiol Biotechn 11, 902-905.

22. Hikino H \& Mizuno T (1989) Hypoglycemic actions of some heteroglycans of Ganoderma lucidum fruit bodies. Planta Med 55, 385-385.

23. Wachtel-Galor S, Tomlinson B \& Benzie IFF (2004) Ganoderma lucidum ('Lingzhi'), a Chinese medicinal mushroom: biomarker responses in a controlled human supplementation study. Brit J Nutr 91, 263-269.

24. Teng BS, Wang CD, Yang HJ, et al. (2011) A protein tyrosine phosphatase 1B activity inhibitor from the fruiting bodies of Ganoderma lucidum (Fr.) Karst and its hypoglycemic potency on streptozotocin-induced type 2 diabetic mice. J Agr Food Chem 59, 6492-6500.

25. Kobayashi K, Forte TM, Taniguchi S, et al. (2000) The $d b / d b$ mouse, a model for diabetic dyslipidemia: molecular characterization and effects of Western diet feeding. Metabolism $\mathbf{4 9}$, $22-31$.

26. Kodama H, Fujita M \& Yamaguchi I (1994) Development of hyperglycaemia and insulin resistance in conscious genetically diabetic (C57BL/KsJ-db/db) mice. Diabetologia 37, 739-744.

27. Folch J, Lees M \& Sloane Stanley GH (1957) A simple method for the isolation and purification of total lipides from animal tissues. J Biol Chem 226, 497-509.

28. Chernoff J, Schievella AR, Jost CA, et al. (1990) Cloning of a cDNA for a major human protein-tyrosine-phosphatase. Proc Natl Acad Sci U S A 87, 2735-2739.

29. Bialy L \& Waldmann H (2005) Inhibitors of protein tyrosine phosphatases: next-generation drugs? Angew Chen Int Ed Engl 44, 3814-3839.

30. Seiner DR, Labutti JN \& Gates KS (2007) Kinetics and mechanism of protein tyrosine phosphatase $1 \mathrm{~B}$ inactivation by acrolein. Chem Res Toxicol 20, 1315-1320.

31. Liu DG, Gao Y, Voigt JH, et al. (2003) Acylsulfonamide-containing PTP1B inhibitors designed to mimic an enzyme-bond water of hydration. Bioorg Med Chem Lett 13, 3005-3007.

32. Liu GX, Tan JZ, Niu CY, et al. (2006) Molecular dynamics stimulations of interaction between protein-tyrosine phosphatase $1 \mathrm{~B}$ and a bidentate inhibitor. Acta Pharmacol Sin 27, 100-110.

33. Asante-Appiah E, Patel S, Dufresne C, et al. (2002) The structure of PTP1B in complex with a peptide inhibitor reveals an alternative binding mode for bisphosphonates. Biochemistry 41, 9043-9051.

34. Bartlett AH \& Park PW (2010) Proteoglycans in host-pathogen interactions: molecular mechanism and therapeutic implications. Exp Rev Mol Med 12, 1-22.

35. Bach-Knudsen KE \& Jørgensen H (2007) Impact of wheat and oat polysaccharides provided as rolls on the digestion and absorption processes in the small intestine of pigs. J Sci Food Agr 87, 2399-2408.

36. Liu G, Xin ZL, Liang H, et al. (2003) Selective protein tyrosine phosphatase 1B inhibitors: targeting the second phosphotyrosine binding site with non-carboxylic acid-containing ligands. J Med Chem 46, 3437-3440.
37. Glover NR \& Tracey AS (1999) Modeling studies of the interaction between the insulin receptor kinase domain and protein tyrosine phosphatase 1B. J Am Chem Soc 121, 3579-3589.

38. Glover NR \& Tracey AS (1999) Nuclear magnetic resonance and restrained molecular dynamics studies of the interaction of an epidermal growth factor-derived peptide with protein tyrosine phosphatase 1B. Biochemistry 38, 5256-5271.

39. Tagami S, Sakaue S, Honda T, et al. (2002) Effects of troglitazone on skeletal muscle and liver protein tyrosine phosphatase activity in insulin-resistant Otsuka Long-Evans Tokushima fatty rats. Curr Ther Res 63, 572-586.

40. Tagami S, Honda T, Yoshimura H, et al. (2002) Triglitazone ameliorates abnormal activity of protein tyrosine phosphatase in adipose tissues of Otsuka Long-Evans Tokushima fatty rats. Tohoku J Exp Med 197, 169-181.

41. Haj F, Zabolotny JM, Kim Y, et al. (2006) Liver-specific protein tyrosine phosphatase 1B (PTP1B) re-expression alters glucose homeostasis of PTP1B ${ }^{-1-}$ mice. J Biol Chem 280 , $15038-15046$.

42. Fukuda S, Ohta T, Sakata S, et al. (2010) Pharmacological profiles of a novel protein tyrosine phosphatase $1 \mathrm{~B}$ inhibitor, JTT-551. Diabetes Obes Metab 12, 299-306.

43. Wang ZQ, Ribnicky D, Zhang XH, et al. (2011) An extract of Artemisia dracunculus L. enhances insulin receptor signaling and modulates gene expression in skeletal muscle in KK-A $\mathrm{A}^{\mathrm{y}}$ mice. J Nutr Biochem 22, 71-78.

44. Mao XQ, Yu F, Wang N, et al. (2009) Hypoglycemic effect of polysaccharide enriched extract of Astragalus membranaceus in diet induced insulin resistant $\mathrm{C} 57 \mathrm{BL} / 6 \mathrm{~J}$ mice and its potential mechanism. Phytomedicine 16, 416-425.

45. Wu Y, Ou-Yang JP, Wu K, et al. (2005) Hypoglycemic effect of Astragalus polysaccharide and its effect on PTP1B. Acta Pharmacol Sin 26, 345-352.

46. Bosch F, Pujol A \& Valera A (1998) Transgenic mice in the analysis of metabolic regulation. Annu Rev Nutr 18, 207-232.

47. Kim MK, Chae YN, Son MH, et al. (2008) PAR-5359, a wellbanlanced PPAR $\alpha / \beta$ dual agonist, exhibits equivalent antidiabetic and hypolidemic activities in vitro and in vivo. Eur J Pharmacol 595, 119-125.

48. Bhavsar SK, Singh S, Giri S, et al. (2009) Effect of saponins from Helicteres isora on lipid and glucose metabolism regulating genes expression. J Ethnopharmacol 124, 426-433.

49. Matveyenko AV, Dry S, Cox HI, et al. (2009) Beneficial endocrine but adverse exocrine effects of sitagliptin in the human islet amyloid polypeptide transgenic rat model of type 2 diabetes interactions with metformin. Diabetes 58, 1604-1615.

50. Bhattarai BR, Ko JH, Shrestha S, et al. (2007) Inhibition of IKK- $\beta$ : a new development in the mechanism of the antiobesity effects of PTP1B inhibitors SA18 and SA32. Bioorg Med Chem 20, 1075-1077.

51. Garber AJ (2002) Attenuating CV risk factors in patients with diabetes: clinical evidence to clinical practice. Diabetes Obes Metab 4, S5-S12.

52. Tao R, Ye F, He YB, et al. (2009) Improvement of high-fatdiet-induced metabolic syndrome by a compound from Balanophora polyandra Griff in mice. Eur J Pharmacol 616, 328-333.

53. Yamabe N, Noh JS, Park CH, et al. (2010) Evaluation of lognan, iridoid glycoside from Corni fructus, on hepatic and renal glucolipotoxicity and inflammation in type 2 diabetic $d b / d b$ mice. Eur J Pharmacol 648, 179-187.

54. Gum RJ, Gaede LL, Koterski SL, et al. (2003) Redution of protein phosphatase $1 \mathrm{~B}$ increase insulin-dependent signaling in ob/ob mice. Diabetes 52, 21-28. 